\title{
ROLE OF TECHNOLOGY IN THE
}

\section{ENVIRONMENTAL PERFORMANCE OF THE BRAZILIAN CHEMICAL INDUSTRY}

\author{
ROBERTO GIRO MOORI \\ Universidade Presbiteriana Mackenzie, São Paulo, São Paulo, Brazil.
}

\section{FABIO YTOSHI SHIBAO \\ MARIO ROBERTO DOS SANTOS}

Universidade Nove de Julho, São Paulo, São Paulo, Brazil.

To cite this paper: Moori, R., Shibao, F. Y., \& Santos, M. R. dos. (2018). Role of technology in the environmental performance of the Brazilian chemical industry. Revista de Administração Mackenzie, 19(1). doi 10.1590/1678-6971/eRAMR180094

Submission: Jul. 07, 2017. Acceptance: Sep. 14, 2017.

\section{(cc) $\mathbf{B Y}$} This is an open-access article distributed under the terms of the Creative Commons Attribution License.

\footnotetext{
This paper may be copied, distributed, displayed, transmitted or adapted if provided, in a clear and explicit way, the name of the journal, the edition, the year and the pages on which the paper was originally published, but not suggesting that RAM endorses paper reuse. This licensing term should be made explicit in cases of reuse or distribution to third parties. It is not allowed the use for commercial purposes.

Este artigo pode ser copiado, distribuído, exibido, transmitido ou adaptado desde que citados, de forma clara e explícita, o nome da revista, a edição, o ano e as páginas nas quais o artigo foi publicado originalmente, mas sem sugerir que a RAM endosse a reutilização do artigo. Esse termo de licenciamento deve ser explicitado para os casos de reutilização ou distribuição para terceiros. Não é permitido o uso para fins comerciais.
} 


\section{ABSTRACT}

Purpose: The objective of this study is to examine the mediating effects of technology on the relationship between green supply chain management and performance of the Brazilian chemical industry.

Originality/Value: The pressure for sustainable environment has emerged in companies, the incorporation of technologies as part of the manufacture of products. However, incorporating technologies into manufacturing does not always represent a reduction of the environmental burden. They can cause environmental externalities. The article makes it easier to understand the role of these technologies in the management of the green supply chain.

Design/methodology/approach: It was considered of descriptive nature of the quantitative type. The data were collected through a semistructured questionnaire with a sample consisting of 160 Brazilian chemical companies. Processed by structural equation modeling, it generated an empirical theoretical model composed of three main constructs: technology, green supply chain management and environmental performance.

Findings: The application of the theoretical empirical model revealed that the technology partially mediates the relationship between green supply chain management and the environmental performance of Brazilian chemical companies. There was evidence that technologies provided tangible competitive advantages, although several of them could only be achieved in the long term. The study suggested implications of theoretical nature, such as having an integrated managerial vision between company and environment; and of practical nature in which new ways of designing products can reduce environmental externalities, often without any technology being used to so.

\section{KEYWORDS}

Green supply chain management. Chemical industry. Externalities. Technology. Environmental performance. 


\section{INTRODUCTION}

The global consensus that greenhouse gases emissions must be curtailed has prompted many production sectors to lighten or mitigate the environmental impacts of their activities: for example, agribusinesses are investing in cutting-edge technologies that analyze the spatial variability of plantations, in order to ensure more efficient use of input materials (Porter \& Heppelmann, 2014); civil construction firms are investing in workyard mechanization technologies that slash project costs through higher output and less waste; in the chemical sector, companies are investing in safety, security, health, environment, and quality assessment technologies that are steadily eliminating risks and lowering accident rates across the board during the distribution, handling and shipment of chemical products, as well as in storage terminals and cleaning stations (Associação Brasileira da Indústria Química [Abiquim], 2015).

As part of this drive to mitigate environmental impacts and fueled by keen competition, Green Supply Chain Management (GSCM) has emerged during the past few years as an extension of Supply Chain Management $(\mathrm{SCM})$. As a result, information and process technologies now play leading roles for drawing up strategies in a context of fierce competition and pressing environmental demands. However, among companies in the chemical industry - already tagged as environmental polluters - linkages between technology and competitive performances are often not properly understood (Ritzman \& Krajewski, 2002). For example, when a company acquires new equipment, it deploys technology in pursuit of a competitive advantage through stepping up the product value to the customer or cutting the costs of placing its goods on the market. This equipment may require a betterqualified workforce, thus upgrading job quality and the workplace. However, it may also be noisy, leak contaminants into the soil or have other undesirable effects. These aspects are tightly tied to the price that society will have to pay in order to resolve external environmental issues caused by companies (Coase, 1937).

In this context, technology per se is not always the best option, as it might not introduce a competitive advantage or be economically justifiable, not matching the desired social profile or failing to reach the required level of environmental sustainability. In order to better understand the role of technology in supply chains, the following question was posed for this research project: does technology mediate linkages between GSCM and environmental performance? The objective was to examine the importance 
of technology in GSCM in order to upgrade environmental performances from the standpoint of company managers in the Brazilian chemical industry.

This paper is structured as follows: after this introduction, the Theoretical Framework is outlined, together with the respective Hypotheses; next is a description of the methodological procedures used during the field survey and the data analyses with their findings. Finally, the Conclusions are presented, followed by suggestions for future research projects.

\section{THEORETICAL FRAMEWORK}

\subsection{GSCM and performance: direct effects}

To an increasing extent, the issue of GSCM is drawing the attention of researchers and other professionals, prompted by rising concern over the heavy environmental impacts of industrial operations (Hashemi, Amir, \& Tavana, 2015) and forcing organizations to develop innovative management techniques that endow them with a keener competitive edge (Rao \& Holt, 2005).

Sweeping changes have altered specific types of environmental management structures, operating within their functional boundaries that assign environmental accountability during the product development stage, as well as operations, logistics and overseeing compliance with environmental rules and regulations controlling solid wastes (Srivastava, 2007). The quality revolution model that appeared in the 1980s and the advent of supply chains during the subsequent decade clearly underscored that the best environmental management integration practice is to keep pace with production operations. Along these lines, Bacallan (2000) suggested that organizations could hone their competitive edges through upgrading their environmental performances while, at the same time, complying with environmental regulations and mitigating the environmental impacts of their services and production activities.

Rooted in environmental management and supply chain literature, GSCM resembles SCM, whose functional boundaries depend on research objectives. The definition and scope of GSCM encompass the origin or supply of environmentally sustainable goods (also known as green supply) to manufacturers, extending through to consumers. A formal definition of GSCM is given by Srivastava (2007) as the "integration of environmental issues into supply chain management, including product design, selection and acquisition of input materials, fabrication processes, deliveries of 
products to consumers, management of the useful life cycles of these products and their return when no longer of use".

Linton, Klassen, and Jayaraman (2007) argue that the convergence between SCM and environmental sustainability is driven by upgrading local environmental factors for production chains, including fabrication processes, consumption, customer services, and the storage, disposal and elimination of solid wastes generated by the products during the post-consumption phase. Furthermore, they add that convergence is a critical and timely topic that reflects rising concern over sustainability, whether underpinned by laws, the public interest or competitive opportunities.

In a comparative analysis of GSCM practices, Zhu, Geng, Fujita, and Hashimoto (2010) showed that major Japanese manufacturers are more active and effective than their Chinese counterparts. The key GSCM aspects studied were: green procurement; customer cooperation on environmental issues; environmentally friendly design; and payback on investments. However, during the initial stage of implementing GSCM practices, Japanese manufacturers posted significantly better environmental and financial performances, despite little improvement on the operations side.

Another study conducted by Pazirandeh and Jafari (2013) examining multinational logistics and transportation companies headquartered in Northern Europe showed that their environmental sustainability strategies were focused on "greening" their carrier activities from the procurement and operations standpoints, in order to upgrade their environmental performances.

This consequently indicates that:

$\mathrm{H}_{1}$ : There is a direct link between GSCM and Performance

\subsection{GSCM and performance: Indirect Effects and the technology mediation}

Technology is conceptualized from a plurality of standpoints which may be limited, such as that defined by Woodward (1970) who views technology as "[...] the process of producing goods inherent to the equipment used in such production" or broad-ranging, as outlined by Burgelman, Christensen, and Wheelwright (2008), referring to technology as:

[...] the theoretical and practical knowledge, skills and instruments that will be used to develop products and services, as well as their production and distribution systems. They may be incorporated in 
people, materials, cognitive and physical processes, installations, facilities, equipment and tools. Their key elements may be implicit, existing only in a deep-rooted manner, such as knowhow-based business secrets, for example.

An even broader-ranging view presented by Shrivastava (1995) includes technology among environmental preservation requirements, defining it as production equipment, methods and procedures, product designs and product delivery mechanisms that conserve natural resources and energy while mitigating the environmental burden of human activities and protecting the natural environment. This includes hardware such as pollution control equipment, environmental metering instruments and cleaner production technologies, as well as operating methods such as solid wastes management practices (recycling materials) and work contracts slanted towards conservation (flexible working hours, carpooling), all designed to conserve and enhance natural environments.

According to Porter (1985), technology ranks among the key factors that set competition rules, and for Burgelman et al. (2008), it is important for technology managers to know what technology systems actually do, rather than how they do it. These managers do not need an engineering background, but should rather invest significant efforts in understanding technologies that are important for their businesses. In addition to pinpointing secure and trustworthy sources of technical advice, they must also be able to address key strategic issues, dealing capably with the costs, changes or scopes (Porter, 1985) of the adopted technologies.

Together with flexible manufacturing systems, machines and equipment, modern technologies demand massive capital investments by the chemical industry. As a result, companies must carefully weigh the economic and environmental benefits of these future acquisitions, together with internal and external factors, in terms of corporate technology strategies. In order to remain competitive and avoid halts or downtime due to environmental problems, investments are often channeled to technologies that lessen water, electricity and raw material consumption, together with scrap retrieval and recycling programs for used materials and depreciated equipment (Ninlawan, Seksan, Tossapol, \& Pilada, 2010; Zhu et al., 2010),

Similar to paint factories, petrochemical plants and paper mills, the entire chemical industry has long been subject to heavy social and environmental pressures prompted by accidents resulting in environmental disasters that occur more frequently and at larger scales than in other 
segments (Zhu et al., 2010). Furthermore, equipment working with special technologies is also common throughout the chemical industry, whether location-specific or dedicated. As many products are inflammable and thus hazardous to transport, logistics costs are consequently high.

It may thus be assumed that:

$\mathbf{H}_{1 \mathrm{a}}$ : There is an indirect link between GSCM and Performance

\subsection{GSCM and Technology}

Green Supply Chain Management is part of a global drive towards environmentally sustainable development (Larson, Teisberg, \& Johnson 2000), with pressures from a wide assortment of economic and social groups prompting companies linked into supply chains to implement similar environmental and social practices. Krause, Vachon, and Klassen (2009) noted that no company, standing alone, can be more environmentally sustainable then its supply chain. In other words, the suppliers selected to join this chain are more environmentally sustainable than the hub company. The direct implication of this is that functions extending beyond organizational boundaries - such as procurement and logistics - play key roles in underpinning the quest for sustainable development.

This is where GSCM may directly influence manufacturing technologies (Srivastava, 2007) and integration activities (Vachon \& Klassen, 2006). Due to easy availability and rapidly-changing technologies, managers must make decisions that are seamlessly aligned with corporate and operating strategies in order to ensure competitive advantages that are also environmentally stable. Decisions on technology focused only on a single department or function may impact only part of an organization.

Introducing technology lessens the possibility of human error, thus upgrading product quality while shortening delivery periods, and may also mitigate environmental damages through implementing systems that reduce pollutive noise and gas emissions or cut back on solid wastes, for example. Obviously, there is also a downside to technology: costs may be prohibitive, particularly for complex and expensive projects requiring new premises or complete refits of current facilities, and these investments may also be high-risk due to uncertain demands. This is why management must weigh the benefits of technology and its associated costs (Hall, 2002). Along these lines, Zhu and Sarkis (2004) noted that investments in technology may be extremely expensive, with environmental performances 
that are not always assured. This underscores the need for a better understanding of GSCM practices.

For Srivastava (2007), manufacturing and remanufacturing technologies are crucial GSCM areas for ensuring minimal use of energy, resources and new feedstock. Soaring costs are pumped up by environmental liabilities and environmental aspects can balloon into increasingly complex and uncertain issues requiring close attention, especially for foreign corporations whose environmental performances differ from those of their Brazilian counterparts (Jaikumar, Karpagam, \& Thiyagarajan, 2013). Multinational corporations must often decide between following their own global corporate directives or complying with local requirements, and thus are forced to tailor their global environmental standards to a wide variety of local government regulations.

Moreover, Epstein and Roy (1998) add that the equipment and plant age affect corporate environmental performances. Multinational corporations working to global environmental standards and explicitly defined environmental performance targets may opt for international systems such as the ISO 14001 standard, or may adapt them to local environmental strategies.

This consequently leads to the assumption that:

$\mathrm{H}_{2}$ : There is a direct link between GSCM and Technology

\subsection{Technology and Performance}

As an important factor for building up comparative advantages, technology must be managed like any other aspect of production processes (Ritzman \&Krajewski, 2002). It may create completely new products, drastically reshape markets and fuel a far greater lead over the competition (Porter, 1985). Comparative advantages are built up not only by new technologies, but also through the deployment and integration of facilities that are already in place. Modifying processes while creating new products and services, technology advances in many different ways, starting out from ideas, expertise and experience that are then woven into new and better ways of doing things.

According to Gavronski, Klassen, Vachon, and Nascimento (2011), investments in technology related to environmental management, process pollution, product recovery, and prevention and mitigation projects are capital allocations designed to upgrade the environmental performances of industrial plants. These investments underwrite the development of complex 
competences (Lucas, 2010). A study by Klassen (2000) showed that environmental investments are positively linked to investments in manufacturing, provided that they are planned in organizational budgets with management agendas that embody external factors in environmental performances (Bansal, 2005).

In transaction cost theory approach (Coase, 1937), external factors are based on the assumption that companies operate on imperfect markets, engaging in multidimensional complex transactions (Vachon and Klassen, 2006). A manufacturing company may generate a negative external factor by emitting toxic gases that adversely affect the health of its neighbors; in compensation, the polluter generates a positive external factor by encouraging new businesses to open nearby. Similarly, Zhu and Sarkis (2004) used the institutional theory concept (normative, coercive and mimetic) based on the assumption that companies are able to influence the adoption of GSCM initiatives. This means that a manufacturer posts positive economic performances (defined as benefits obtained through GSCM) in parallel to negative economic performances (defined as heavier investments and higher costs). A study of GSCM practices conducted in a sample of 186 Chinese manufacturers during 2004 concluded that GSCM practices are linked positively to both positive and negative environmental performances.

Nevertheless, in order to mitigate negative external factors, the company will be subject to new rules or directives supplementing current environmental legislation. Consequently, for Lamming and Hampson (1996), compliance with environmental legislation may pump up corporate costs. Companies with good environmental performances can cut costs through eliminating waste, which may be hard to measure, resulting in bottom lines that reflect uneven corporate results. However, Nehrt (1996) has shown that investments in environmental technologies have positive impacts on financial performances. A study conducted by Rothenberg, Pil, and Maxwell (2001) of 31 auto-assemblers in the USA and Japan showed that, on the one hand, lean production or JIT manufacturing schemes stepped up emissions of volatile organic compounds; while on the one hand, lead to more efficient use of materials such as paints and solvents, reaching the conclusion that three lean management aspects (lean inventories, trim work systems and effective human resource management) were linked to environmental management practices and performances.

Along these lines, Saridogan (2012) argued that several reasons could explain GSCM in lean production schemes, such as mitigating in-house supply chain impacts on the environment and upgrading environmental 
performances through leaner inventories, less wasted materials and fewer hazardous wastes.

This consequently leads to the assumption that:

$\mathbf{H}_{3}$ : There is a direct link between Technology and Performance

\section{METHOD}

This descriptive quantitative research project addresses a population consisting of companies in the Brazilian chemical industry in order to draw inferences from the characteristics of the phenomena under analysis. An easy-access sample was taken from this total, where data were collected from managers engaged in activities related to the procurement, engineering, environment, logistics and production areas.

A semi-structured questionnaire was used to collect data, divided into six sections. The first and second sections sought information on the company and the respondents, while the third, fourth and fifth sections respectively gathered data on the GSCM, Technology and Performance constructs. These final three sections consisted of statements with reply options that varied between Disagree Totally $(\mathrm{DT}=1)$ and Agree Totally $(\mathrm{AT}=6)$, where the respondents marked (with an X) the level of importance of each statement as they saw it, ranked from the company standpoint.

Before this questionnaire was forwarded to the respondents, it was pre-tested by seven GSCM, operations and logistics specialists in order to upgrade and refine this research tool. Although basically selected for ease of access, these specialists were also required to demonstrate a critical comprehension of the concepts to be explored, living and working in different parts of Brazil in order to avoid regional distortions.

The final version of this questionnaire consisted of thirty statements, distributed as follows: ten statements on GSCM constructs; five on Technology; and fifteen on Environmental Performance, subdivided into Economic Performance, Positive External Factors and Negative External Factors, each with five statements

The questionnaire was emailed to chemical companies in Brazil, followed up by telephone calls and a second email message stressing the importance of completing and returning the questionnaire. In some cases, a researcher travelled to meet a respondent.

Once collected, the data were initially treated through descriptive statistics, in order to examine the characteristics of the respondents, the 
companies and the replies to the statements. Questionnaires that were incomplete, with unanswered items or atypical information were excluded.

The distribution format of the collected data was checked from the univariate (mean, standard deviation, format) and bivariate (correlation) standpoints, followed by exploratory and confirmatory factor analysis in order to refine and define the underlying structure. Hair Junior, Anderson, Tatham, and Black (1998) recommend that the factor loading exceed 0.7 for the factor to explain at least $50 \%$ of the variance.

With the measurement model debugged, the unidimensionality and the composite, convergent and discriminant reliability values of the model construct measurements established, unidimensionality was assessed through the internal consistency of the factor loadings for each construct, given by Cronbach's Alpha and taking 0.7 as the threshold acceptability value.

As the internal consistency measurement assumes unidimensionality but does not guarantee that it exists, composite reliability was also assessed, as this is a more reliable construct measurement. The acceptable reference value for both the unidimensionality and composite reliability measurements was 0.7, acceptable at below 0.7 for exploratory surveys (Hair Junior et al., 1998).

Convergent validity was assessed by Factor Loadings and Average Variance Extracted (AVE). Both the Factor Loadings and the Average Variance Extracted (AVE) have reference values of more than 0.50 (Hair Junior et al., 1998). Discriminant validity was assessed by the Fornell and Larcker (1981) criterion, considered adequate when the square root of the Average Variance Extracted (AVE) exceeds the construct correlation shared with others in the measurement model.

In order to examine the statistical significances and forces among the model constructs, structural equation modelling was used through Partial Least Squares - Path Modeling (PLS-PM), due to the following characteristics: i) PLS-PM is based on partial least squares; ii) it can work with small samples (Smith \& Langfield-Smith, 2004); iii) it allows the absence of probability distribution properties such as normality, for example, and allows the use of Likert scales (Jöreskog \& Sörbom, 1993); iv) relative forces among variables may be inferred from the factor loadings (Fornell \& Larcker, 1981); v) it allows bootstrapping to assess the statistical significance of the coefficients; vi) allows the construction of a second-order construct. In this case, as recommended by Wetzels, Odekerken-Schroder, and Oppen (2009), the measurements of the first-order constructs are repeated in the secondorder construct, whose factorial loads obtained are used to determine the Composite Reliability (CR) and the Average Variance Extracted (AVE) and; vii) the adjustment of the measurement model can be obtained by the 
coefficient of determination $\left(\mathrm{R}^{2}\right)$, relevance, predictive validity or indicator of Stone-Geisser $\left(\mathrm{Q}^{2}\right)$ and by size effect or indicator of Cohen $\left(\mathrm{f}^{2}\right)$. As parameter to decision taken for $\left(R^{2}\right)$, according to Cohen $(1988),\left(R^{2}\right)$ equal to 0.02 can be classified as a small effect, $\left(R^{2}\right)$ equal to 0.13 as a medium effect, and $\left(R^{2}\right)$ equal to 0.26 as a large effect. For the $\left(Q^{2}\right)$, the values must be positive; and for $\left(\mathrm{f}^{2}\right)$ values equal to $0.02,0.15$ and 0.35 for model adjustment considered: small, medium and large, respectively.

To test the mediation of the Technology between GSCM and Performance it was used the approach of Hair Junior, Hult, Ringle, and Sarstedt (2014) by means of the test of Variance Accounted For (VAF) given by: $\operatorname{VAF}=\left[\frac{\beta_{12} x \beta_{23}}{\left(\beta_{12} x \beta_{23}\right)+\beta_{13}}\right] \rightarrow$ Equation [1], where $\beta_{12}, \beta_{23}$ e $\beta_{13}$ are the structural coefficients captured by relationships between the constructs [GSCM and Technology], [Technology and Environmental Performance] and [GSCM and Environmental Performance], respectively. For VAF value $>80 \%$ means full mediation, VAF $<20 \%$ there is no mediation, and $20 \% \leq \mathrm{VAF} \leq 80 \%$ the mediation is partial.

Limitations of the method: The main limitations of this research method were: a) use of a non-random sample of Brazilian companies that might possibly skew the replies of the research subjects; b) sample size. Despite using the PLS-PM technique that does not require data normality, the level of five respondents per variable was not attained (Hair Junior et al., 1998); and c) the interdisciplinary nature of this research project, with blurred boundaries demarcating correlated areas of expertise such as production, marketing, operations, logistics, supply chain and environment, making this analysis harder and more complex. These findings must consequently be construed with caution.

\section{DATA ANALYSIS AND FINDINGS}

Collected between August 2015 and January 2016, data were collected from 1,107 emailed questionnaires, of which $14.4 \%$ were completed and returned, resulting in 160 valid questionnaires.

\subsection{Company Sample Profile}

With regard to the positions of the respondents, $16(10 \%)$ were company officers or directors; 36 (22\%) were managers; 28 (18\%) were coordinators 
and 80 (50\%) were employed in supervisory positions. Among them, 31 (20\%) had not finished university; 58 (36\%) were university graduates; and $71(44 \%)$ held graduate degrees. With regard to the length of time in their jobs, $20 \%$ reported less than two years, $29 \%$ between two and five years and $51 \%$ more than five years. Finally, for length of service with the company, $12 \%$ reported less than two years, $18 \%$ between two and five years and $70 \%$ more than five years.

With regard to the companies, $129(80 \%)$ were located in the Southeast; $14(9 \%)$ in the South; and $13(11 \%)$ elsewhere in Brazil. Among them, $29 \%$ reported annual revenues of more than $\mathrm{R} \$ 60$ million, with the rest reporting annual revenues of less than $\mathrm{R} \$ 60$ million; 82\% held ISO 9001 certification and $29 \%$ were certified under the ISO 14001 standards. In terms of products, $46 \%$ produced industrial chemicals; $5 \%$ soaps and detergents; and the rest worked with pharmaceuticals, paints, dyes, varnishes, toiletries, pesticides, manures and fertilizers. Overall, $60 \%$ of these companies declared that they were partially integrated with GSCM and 35\% were fully integrated with GSCM.

\subsection{Validation of Construct Scales and Measurements}

The SmartPLS 2.0 factor analysis software was used to validate the scales and measurements of the data collected from 160 respondents. After several runs and interventions, a basic structure was obtained consisting of 21 statements with factor loadings of more than 0.72 , with a recommended value of 0.7 , divided into five constructs: GSCM, with six statements, Technology, with four statements, Economic Performance, with four statements, Positive External Factor, with three statements, and Negative External Factor, with four statements. Out of the original total of thirty statements, $21(70 \%)$ remained. This $30 \%$ cut in the total number of statements may be justified by inadequate sample size, lack of clarity or poor understanding of statements. Suggestions on minimizing statement discards are presented at the end of this paper.

The factor loadings for each of the statements are presented on Table 1, cleaned up in their respective constructs. 


\section{(Table 1)}

THE FACTOR LOADING FOR EACH STATEMENT

\begin{tabular}{|c|c|c|c|c|c|}
\hline \multirow{3}{*}{ Construct / Statements } & \multirow{3}{*}{ GSCM } & \multirow{3}{*}{ Technology } & \multicolumn{3}{|c|}{ Performance } \\
\hline & & & \multirow{2}{*}{ Economic } & \multicolumn{2}{|c|}{ Externality } \\
\hline & & & & Positive & Negative \\
\hline \multicolumn{6}{|l|}{ GSCM - Green Supply Chain Management } \\
\hline $\begin{array}{l}\text { GVI - Commitment of senior } \\
\text { management }\end{array}$ & 0.764 & 0.341 & 0.262 & 0.250 & 0.460 \\
\hline $\begin{array}{l}\text { GV2 - Support for managers and } \\
\text { supervisors }\end{array}$ & 0.793 & 0.431 & 0.147 & 0.291 & 0.482 \\
\hline GV3 - Active environmental management & 0.792 & 0.369 & 0.257 & 0.352 & 0.557 \\
\hline $\begin{array}{l}\text { GV4 - Employees assign high priority to } \\
\text { environmental issues }\end{array}$ & 0.828 & 0.391 & 0.211 & 0.374 & 0.580 \\
\hline $\begin{array}{l}\text { GV5 - Managers devote time to } \\
\text { environmental issues }\end{array}$ & 0.894 & 0.502 & 0.243 & 0.357 & 0.526 \\
\hline $\begin{array}{l}\text { GV6 - Management assigns priority to } \\
\text { environmental issues }\end{array}$ & 0.896 & 0.382 & 0.272 & 0.305 & 0.576 \\
\hline \multicolumn{6}{|l|}{ Technology. [Invests in...] } \\
\hline $\begin{array}{l}\text { TEl - Equipment reducing electricity } \\
\text { consumption }\end{array}$ & 0.416 & 0.811 & 0.193 & 0.352 & 0.317 \\
\hline $\begin{array}{l}\text { TE2 - Equipment reducing water } \\
\text { consumption }\end{array}$ & 0.312 & 0.816 & 0.158 & 0.419 & 0.279 \\
\hline $\begin{array}{l}\text { TE3 - Equipment reducing pollutant } \\
\text { emissions }\end{array}$ & 0.443 & 0.849 & 0.150 & 0.403 & 0.461 \\
\hline $\begin{array}{l}\text { TE4 - Raw material that is less } \\
\text { environmentally harmful }\end{array}$ & 0.430 & 0.847 & 0.215 & 0.494 & 0.405 \\
\hline \multicolumn{6}{|c|}{ Economic Performance... [during the past two years.] } \\
\hline DE1 - Higher operating costs ... & 0.206 & 0.146 & 0.856 & 0.280 & 0.233 \\
\hline DE2 - Higher training costs ... & 0.319 & 0.176 & 0.880 & 0.265 & 0.253 \\
\hline DE3 - Higher raw material costs ... & 0.178 & 0.141 & 0.872 & 0.256 & 0.233 \\
\hline $\begin{array}{l}\text { DE4 - Higher outlays on training/ } \\
\text { awareness-heightening... }\end{array}$ & 0.244 & 0.270 & 0.785 & 0.320 & 0.285 \\
\hline
\end{tabular}




\section{(Table 1 (conclusion)) \\ THE FACTOR LOADING FOR EACH STATEMENT}

\begin{tabular}{|c|c|c|c|c|c|}
\hline \multirow{3}{*}{ Construct / Statements } & \multirow{3}{*}{ GSCM } & \multirow{3}{*}{ Technology } & \multicolumn{3}{|c|}{ Performance } \\
\hline & & & \multirow{2}{*}{ Economic } & \multicolumn{2}{|c|}{ Externality } \\
\hline & & & & Positive & Negative \\
\hline \multicolumn{6}{|l|}{ Positive External Factors } \\
\hline $\begin{array}{l}\text { DP1 - Products that lower material } \\
\text { consumption }\end{array}$ & 0.367 & 0.494 & 0.270 & 0.836 & 0.337 \\
\hline $\begin{array}{l}\text { DP2 - Implementation of recycling with } \\
\text { customers }\end{array}$ & 0.257 & 0.420 & 0.325 & 0.777 & 0.323 \\
\hline $\begin{array}{l}\text { DP3 - Reverse logistics and product } \\
\text { designs }\end{array}$ & 0.294 & 0.247 & 0.168 & 0.737 & 0.293 \\
\hline \multicolumn{6}{|l|}{ Negative External Factors } \\
\hline $\begin{array}{l}\text { DN1 - Compliance with environmental } \\
\text { legislation }\end{array}$ & 0.491 & 0.367 & 0.267 & 0.357 & 0.834 \\
\hline DN2 - Minimizing environmental liabilities & 0.574 & 0.487 & 0.218 & 0.353 & 0.845 \\
\hline $\begin{array}{l}\text { DN3 - More stringent environmental } \\
\text { legislation }\end{array}$ & 0.511 & 0.216 & 0.233 & 0.312 & 0.816 \\
\hline DN4 - Same standards as its competitors & 0.489 & 0.373 & 0.237 & 0.2833 & 0.722 \\
\hline
\end{tabular}

Note 1: The statements were measured on a Disagree / Agree scale with six scores ranging from Disagree Totally (DT = 1) to Agree Totally (AT = 6).

All statements were statistically significant for $(\alpha \leq 0.01)$.

Source: Elaborated by the authors.

The construct structures obtained through factor analysis were validated for: a) unidimensionality, given by the Cronbach's Alpha coefficient; and composite reliability, with both measurements above the recommended threshold value of 0.70 ; b) convergent validity, assessed through factor loading and Average Variance Extracted (AVE), also above the respective recommended threshold values of 0.7 and 0.5 ; and c) discriminant validity given by the shared variances and obtained through the square root of the Average Variance Extracted for each construct, which were higher than the correlations between the constructs, as shown in Table 2 (shown in italics on the matrix diagonal).

Descriptive statistical data such as the mean and standard deviation of the constructs, the bivariate correlation, the quantities of original statements 
and statements after cleaning up, the Cronbach's Alpha measurement, the Average Variance Extracted (AVE) and the Composite Reliability (CR) are shown in Table 2.

\section{(Table 2)}

\section{VALIDATION AND BIVARIATE CORRELATION MEASUREMENTS FOR THE CONSTRUCTS}

\begin{tabular}{lcccccccc}
\hline Variables & Mean & $\begin{array}{c}\text { Standard } \\
\text { Deviation }\end{array}$ & 1 & 2 & $3^{(1)}$ & $3_{\mathrm{a}}$ & $3_{\mathrm{b}}$ & $3_{\mathrm{c}}$ \\
\hline 1. GSCM & 4.68 & 0.99 & 0.83 & & & & \\
\hline 2. Technology & 4.80 & 1.08 & $0.49^{* *}$ & 0.83 & & & & \\
\hline 3. Environmental Performance ${ }^{(1)}$ & 4.23 & 0.86 & $0.60^{* *}$ & $0.51^{* *}$ & 0.61 & & & \\
\hline 3. Economic Performance & 3.42 & 1.37 & $0.28^{* *}$ & $0.22^{* *}$ & $0.73^{* *}$ & 0.85 & & \\
\hline 3. Positive External Factors & 5.29 & 0.81 & $0.39^{* *}$ & $0.50^{* *}$ & $0.71^{* *}$ & $0.33^{* *}$ & 0.78 & \\
\hline 3, Negative External Factors & 3.90 & 1.26 & $0.64^{* *}$ & $0.45^{* *}$ & $0.80^{* *}$ & $0.30^{* *}$ & $0.41^{* *}$ & 0.81 \\
\hline Original Measurements & & & 15 & 5 & 15 & 5 & 5 & 5 \\
\hline Final Measurements $\rightarrow$ & & & 6 & 4 & 11 & 4 & 3 & 4 \\
\hline Unidimensionality (Cronbach's Alpha) $\rightarrow$ & 0.91 & 0.85 & 0.83 & 0.87 & 0.69 & 0.82 \\
\hline Average Variance Extracted (AVE) $\rightarrow$ & 0.73 & 0.69 & 0.56 & 0.72 & 0.62 & 0.65 \\
\hline Composite Reliability (CR) $\rightarrow$ & 0.91 & 0.90 & 0.79 & 0.91 & 0.83 & 0.88 \\
\hline
\end{tabular}

Note 1: The diagonal values of the matrix are the square root of the Average Variance Extracted (AVE). As these values are greater than the values outside the diagonal (correlation) indicates that there is discriminant validity between the constructs (Fornell \& Larcker, 1981).

(1) Second order construct.

** Indicates that the statement coefficient is significant at 1\%.

Source: Elaborated by the authors.

Having validated the construct structures with their measurements and scales, the structural linkages of the measurement model were then assessed.

\subsection{Measurement Model Structural Linkages Assessment}

The results obtained through the SmartPLS 2.0 software and the PLS-PM technique are illustrated in Figure 1. 


\section{(Figure 1)}

\section{MEASUREMENT MODEL}

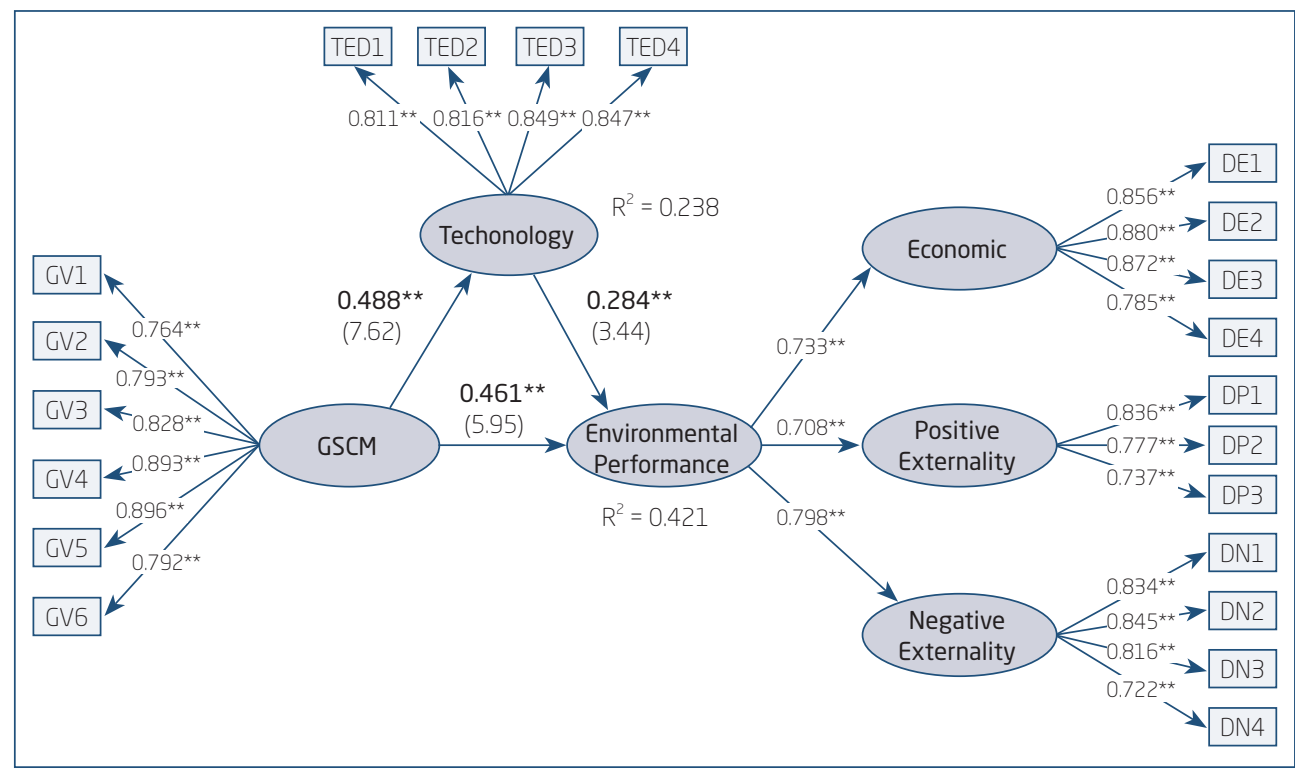

**) Indicates that the statement coefficient is significant at 1\%.

Source: Elaborated by the authors.

Figure 1 presents the statistical significances of the GSCM, Technology and Environmental performance constructs, indicating a statistical significance of $(\alpha \leq 0.05)$, as addressed in the arguments of authors such as Srivastava (2007), Linton et al. (2007) and Zhu et al. (2010). Green Supply Chain Management has a direct effect on environmental performance with a structural coefficient of 0.461 and a t-statistic of 5.95, supporting Hypothesis $\mathrm{H}_{1}$. GSCM impacted Technology with a structural coefficient of 0.488 and a t-statistic of 7.62, supporting Hypothesis $\mathrm{H}_{2}$. Technology, in turn, influenced environmental performance with a structural coefficient of 0.284 and t-statistic of 3.44, supporting Hypothesis $\mathrm{H}_{3}$.

Table 3 presents the structural coefficients, the standard errors and the t-statistic values for the estimation model relations. 


\section{(Table 3)}

STRUCTURAL COEFFICIENTS, STANDARD ERRORS AND T-STATISTIC VALUES

\begin{tabular}{cccccc}
\hline Structural Linkages & $\begin{array}{c}\text { Structural } \\
\text { Coefficients }\end{array}$ & $\begin{array}{c}\text { Standard } \\
\text { Errors }\end{array}$ & $\begin{array}{c}\text { t-Statistic } \\
\text { Value }\end{array}$ & Hypotheses & $\begin{array}{c}\text { Decision } \\
\alpha \leq 0.05\end{array}$ \\
\hline $\begin{array}{c}\text { GSCM } \rightarrow \text { Environmental } \\
\text { performance }\left(\beta_{13}\right)\end{array}$ & 0.461 & 0.077 & 5.95 & $\mathrm{H}_{1}$ & Supports \\
\hline \begin{tabular}{c} 
GSCM $\rightarrow$ Technology $\left(\beta_{12}\right)$ \\
\hline $\begin{array}{c}\text { Technology } \rightarrow \text { Environmental } \\
\text { performance }\left(\beta_{23}\right)\end{array}$
\end{tabular} & 0.488 & 0.064 & 7.62 & $\mathrm{H}_{2}$ & Supports \\
\hline $\begin{array}{c}\text { Performance } \rightarrow \text { Economic } \\
\text {-Performance } \rightarrow \text { Positive Externality } \\
\text { Factors }\end{array}$ & 0.784 & 0.083 & 3.44 & $\mathrm{H}_{3}$ & Supports \\
\hline $\begin{array}{c}\text {-Performance } \rightarrow \text { Negative Externality } \\
\text { Factors }\end{array}$ & 0.708 & 0.053 & 13.71 & & \\
\hline
\end{tabular}

Source: Elaborated by the authors.

The GSCM effect on performance, under influence of the Technology was of 0.461 , i. e, the indirect effect, via Technology, was of 0.139 [0.488* $0.284=0.139]$. The total effect was of $0.600\left[0.461+0.488^{*} 0.284=0.600\right]$. The proportion of mediation of the technology in the variance of the environmental performance explained, directly and indirectly, by GSCM was of $23.2 \%([0.488 * 0.284] /[(0.488 * 0.284)+0.461]=0.232)$. In Table 4 are showed the direct, indirects and total effects.

\section{(Table 4)}

DIRECT, INDIRECT AND TOTAL EFFECTS OF THE MEASUREMENT MODEL CONSTRUCTS

\begin{tabular}{lccc} 
& \multicolumn{3}{c}{ Performance } \\
\cline { 2 - 4 } & Direct Effect & Indirect Effect & Total Effect \\
\hline GSCM & 0.461 & 0.139 & 0.600 \\
\hline Technology & 0.284 & & 0.284 \\
\hline
\end{tabular}

Source: Elaborated by the authors. 
Therefore, with the insertion of the Technology, the total effect of 0.600 reduced to 0.461 , denoting the mediator effect of the variable Technology in the relationship between GSCM and Performance. To verify the typology of mediator effect, if total or partial, it was applied the test of Variance Accounted for (VAF), showed in [Equation 1], whose parameters were extracted of the Table 3, with values to $\beta_{12}=0.488 ; \beta_{23}=0.284$ e $\beta_{13}=0.461$, was obtained:

$$
\mathrm{VAF}=\frac{0.488 \times 0.284}{(0.488 \times 0.284)+0.461}=0.23 \text {. The value } 0.23 \text {, according to the }
$$

approach of Hair Junior et al. (2014) is between the interval $0.20 \leq \mathrm{VAF} \leq 0.80$, therefore, the effect of the mediation was considered partial. Consequently, hypothesis $\mathrm{H}_{1 \mathrm{a}}$ was partially supported using the evaluation of the Variance Accounted For (VAF) proposed by Hair Junior et al. (2014).

Analysis of fit quality measures using Stone-Geisser's indicators, of relevance or predictive validity $\left(\mathrm{Q}^{2}\right)$, and the Cohen's indicators or size effect $\left(\mathrm{f}^{2}\right)$, were obtained the results shown in Table 5.

\section{(Table 5)}

VALUES OF THE INDICATORS OF PREDICTIVE VALIDITY $\left(Q^{2}\right)$ AND SIZE EFFECT $\left(F^{2}\right)$

\begin{tabular}{lcc}
\hline \multicolumn{1}{c}{ Constructs } & CV RED $\left(Q^{2}\right)$ & CV COM $\left(f^{2}\right)$ \\
\hline Green Supply Chain Management (GSCM) & 0.561 & 0.561 \\
\hline Technology & 0.149 & 0.469 \\
\hline Environmental Performance & 0.140 & 0.253 \\
\hline Economic Performance & 0.406 & 0.524 \\
\hline Positive Externality Factors & 0.302 & 0.240 \\
\hline Negative Externality Factors & 0.435 & 0.410 \\
\hline & & 0.02 - Small effect \\
Reference Values & $Q^{2}>0$ & 0.15 - Medium effect \\
\end{tabular}

Source: Elaborated by the authors.

Table 5 shows that the indicator $\left(\mathrm{Q}^{2}\right)$ presented positive values, evidencing that the model reflects reality, that is, without errors. Regarding the size effect indicator $\left(\mathrm{f}^{2}\right)$, the constructs showed values greater than 0.15 and less than 0.35 , denoting that the model had average adjustment quality. 
Another measure of adjustment of the measurement model, given by the coefficient of determination $\left(\mathrm{R}^{2}\right)$, was obtained the mean value of 0.330 $[(0.238+0.421) / 2=0.330]$, which according to Cohen (1988) can be classified as large effect.

Therefore, it can be considered that there was evidence that the data collected had a good fit for the measurement model developed.

\section{CONCLUSIONS}

This study found that Technology partially mediates the linkages between GSCM and environmental performance, leading to the conclusion that chemical companies should opt for Green Supply Chain Management techniques, looking beyond merely economic benefits, as social and environmental issues must also rank high among their concerns. These companies will still encounter hurdles when dealing with environmental matters, with such challenges shaping circumstances favorable to their businesses as they progress along this rocky path.

The implications of these findings are described below, together with the theoretical and practical conclusions reached through this study.

\subsection{Theoretical Implications}

The impact of technology on GSCM is under close examination in many fields of industry, including electronics (Zhu et al., 2010), manufacturing (Rothenberg et al., 2001) and chemicals (Brockhoff, Chakrabarti, \& Kirchgeorg, 1999). According to Coase (1937), companies whose activities are pollutive - like chemical plants - are consequently subject to outside consequences or the side effects of producing goods or services with impacts on the environment and people who are not directly involved with these activities. External factors arising from market flaws may be reduced through internalizing their costs or indirectly through government interventions such as production quotas, pollution taxes or clean-up fees.

In Japanese quality management concepts pursuing zero defects, sustainability remains a moving target, always pushed further ahead whenever a company draws close to reaching its goals, thus ensuring ongoing process upgrades and less industrial waste. Institutions whose production process handbooks include 'green' procurement criteria, environmental certification standards such as the ISO 14000 and wasted water and pollutant gas 
emission monitoring systems have significant effects on building up greener supply chains (Hashemi et al., 2015).

In the civil construction segment, greater consumer awareness has triggered a demand for Leadership in Environmental Energy (LEED) certification and its Brazilian High Environmental Quality counterpart: AQUA (Alta Qualidade Ambiental). These environmental certificates ensure that an enterprise is sustainable from the drawing board onwards. Another initiative for a sustainable planet is prompting companies and conglomerates to adopt the Dow Jones Sustainability Index - World as a global financial performance indicator. Companies listed on this index, which is administered by the New York Stock Exchange, are ranked as the most likely to create value for their shareholders over the long term through effectively managing the risks associated with economic, environmental and social factors.

Even without defining specific sustainable criteria, many new plants or public works will use renewable energy, fitted with equipment that avoids wasting water, hiring local workers and repurposing solid wastes. All this will occur because increasingly large numbers of enterprises must set and meet their own targets in response to market demands. Launched late in the 1980s by the United Nations Environment Programme (United Nations Environment Programme, 2016), cleaner production practices in manufacturing plants - eliminating or storing liquid and solid wastes (pollution) for subsequent treatment and proper disposal - will be used more widely, generating less waste while saving water and energy.

Clean production processes that adopt a holistic view of manufacturing systems (cradle to grave or cradle to rebirth), self-sustainable natural resources, lower consumption of raw materials, water and energy, waste control at source and use, during product life-cycle, assessments must all surmount the massive challenge of embodying ecological principles in current economic and industrial models, replacing the end-of-pipeline standpoint by an approach grounded on waste generation control at source.

This will be a major step forward for global society, as production system attitudes are forced to deal with their environmental consequences. In this context, practices steered by ecology and sustainability will be needed in order to administer new concepts, proposals, strategies and trends, such as clean production, GSCM, eco-friendly management and environmental accountability.

There is consequently a huge theoretical space for exploring the convergence of GSCM and clean production techniques in support of environmental sustainability. 


\subsection{Practical Implications}

With environmental sustainability, a matter of deep concern for societies, governments, and businesses today, GSCM is now acknowledged as a key factor for fostering organizational sustainability (Hsu, Tan, Zailani, \& Jayaraman, 2013). Consequently, sustainable operations ensuring that there is enough for everyone demand constant shifts in technology with public policy flexibility, in parallel to enhanced awareness among consumers. It is thus necessary to look beyond merely cutting back on consumption as: 'it is not a matter of curtailing consumption but rather consuming differently'. Companies must seek out radically new products and services that stress local sourcing, sharing, durability, healthiness and full lifetime use. Good practices do not mean pruning profits, although these two aspects can progress in parallel only through effective management.

Technology - especially information and communication technologies (ICT) - has focused on studies of administrative and organizational practices, together with computer-based production techniques (process technologies). In a study of management practices and production techniques, Hall (2002) mentions that technological innovations in production techniques were introduced at a faster pace than innovations related to management practices. At the same time, adopting an innovative management technology tends to trigger the introduction of innovative production technologies more quickly than the other way around.

According to Porter and Heppelmann (2014), information technology turns products into complex systems blending hardware, sensors, data storage, microprocessors, software and countless types of connectivity. Consisting only of electrical and mechanical parts, smart sensors and connected machines boost processing power and drive device miniaturization, underpinned by the benefits of omnipresent wireless networks, ushering in a new era of competition called the Industrial Era 4.0. A good example of these new times is smart urban wastes management, with finely tuned garbage collection operations and effective input for public policies controlling solid wastes pick-up and disposal procedures (Brasil, 2012).

Fostering sustainable development is today a crucial activity for organizations, keeping their bottom lines firmly in the black while upgrading the quality of life for modern society. In the very near future, there will be no room on the market for companies whose activities are not sustainable; laggards will encounter tough times as competitors provide better and cheaper products that are also reliable and well accepted by consumers. 
Diagnoses must be drawn up and strategies defined, sizing resources and planning their deployment, solving problems, pursuing innovation and ceaselessly seeking a keener competitive edge.

New ways of designing products may mean that huge resource savings are actually less costly than borderline or even no savings at all. And quite often new technology is not even needed to do so.

As its contribution, this study bequeaths the empirical theoretical model to GSCM, associated with the respective constructs and first level measurements validated at a statistically significant level $(\alpha \leq 0.05)$.

Delimitations of this study. The main constraints were: a) the scope of this study was limited to companies in the Brazilian chemical industry posting net revenues of US\$112.4 billion in 2015, with the fourth largest stake in Brazil's Gross Domestic Product and ranking sixth worldwide (Abiquim, 2015) and employing two million people; and b) this research project was conducted through a cross-section, thus examining only a single period.

\subsection{Future Research Projects}

In order to extend this study, new constructs could be inserted in the model; competitive models could be developed and sample size increased; other research universes could be explored, such as the processing, healthcare or logistics sectors.

In a vast nation such as Brazil, with equally pressing social and political problems, that is still trying to achieve fair and favorable economic growth for its population, requiring companies to worry about environmental aspects as well might well seem an aspiration well beyond its grasp.

However, running a business that is not compliant with environmental legislation may be financially more burdensome than striving to preserve the environment. Economic growth is a strategic factor for companies and their survival on competitive markets, as consumers are already opting for goods whose manufacturers are firmly engaged in social and environmental responsibility programs.

Finally, chemical companies must strengthen their links with their suppliers and customers, consolidating GSCM in order to draw up environmental strategies that will reduce waste and preserve the environment, to the benefit of their employees and neighboring communities. Quite clearly, research opportunities are abundant. 


\section{REFERENCES}

Associação Brasileira da Indústria Química (Abiquim). (2015). As perspectivas futuras da indústria química. Retrieved from http://www.abiquim. org.br/pdf/livreto-de-dados-2015-paginas.pdf

Bacallan, J. J. (2000). Greening the supply chain. Business and Environment, 6(5), 11-12.

Bansal, P. (2005). Evolving sustainably: A longitudinal study of corporate sustainable development. Strategic Management Journal, 26(3), 197-218.

Brasil. (2012). Política nacional de resíduos sólidos. Brasília, DF: Ministério do MeioAmbiente. Retrieved from http://www.mma.gov.br/pol\%C3\%ADticade-res\%C3\%ADduos-s\%C3\%B3lidos\#content

Brockhoff, K., Chakrabarti, A. K., \& Kirchgeorg, M. (1999). Corporate strategies in environmental management. Research Technology Management, 42 (4), 26-30.

Burgelman, R. A., Christensen, C. M., \& Wheelwright, S. C. (2008). Strategic management of technology and innovation (5th ed., p. 1280). Boston, MA: McGraw-Hill Irwin.

Coase, R. H. (1937). The nature of the firm. Economica, 4(16), 386-405. Retrieved from http://www.jstor.org/stable/2626876

Cohen, J. (1988). Statistical power analysis for the behavioral sciences (2nd ed.). New York: Routledge.

Epstein, M., \& Roy, M. J. (1998). Managing corporate environmental performance: A multinational perspective. European Management Journal, 16(3), 284-296.

Fornell, C., \& Larcker, D. F. (1981). Structural equation models with unobservable variables and measurement error: Algebra and statistics. Journal of Marketing Research, 18(3), 382-388.

Gavronski, I., Klassen, R. D., Vachon, S., \& Nascimento, L. F. M. (2011). A resource-based view of Green Supply Chain Management. Transportation Research Part E-Logistics and Transportation Review, 47, 872-885.

Hair Junior, J. F., Anderson, R. E., Tatham, R. L., \& Black, W. C. (1998). Multivariate data analysis with readings (4th ed.). New Jersey, NJ: Prentice Hall.

Hair Junior, J. F., Hult, G. T. M., Ringle, C. M., \& Sarstedt, M. (2014). A Primer on Partial Least Squares Structural Equation Modeling (PLS-SEM). Thousand Oaks: Sage. 
Hall, R. H. (2002). Organizations: Structures, processes, and outcomes (8th ed.). Upper Saddle River, NJ: Prentice Hall.

Hashemi, S. H., Amir K. A., \& Tavana, M. (2015). An integrated green supplier selection approach with analytic network process and improved Grey relational analysis. International Journal of Production Economics, 159, 178-191.

Hsu, C., Tan, K. C., Zailani, S. H. M., \& Jayaraman, V. (2013). Supply chain drivers that foster the development of green initiatives in an emerging economy. International Journal of Operations \& Production Management, 33(6), 656-688.

Jaikumar, G., Karpagam, M., \& Thiyagarajan, S. (2013). Factors influencing corporate environmental performance in India. Indian Journal of Corporate Governance, 6(1), 2-17.

Jöreskog, K. G., \& Sörbom, D. (1993). LISREL 8: Users reference guide (2nd ed.). Skokie: Scientific Software International (SSI).

Klassen, R. D. 2000. Exploring the linkage between investment in manufacturing and environmental technologies. International Journal of Operations $\mathcal{E}$ Production Management, 20(2), 127-147.

Krause, D. R., Vachon, S., \& Klassen, R. D. (2009). Special topic forum on sustainable supply chain management: introduction and reflections on the role of purchasing management. Sustainable Supply Chain Management, 45(4), 18-24.

Lamming, R. C., \& Hampson, J. (1996). The environment as a supply chain management issue. British Journal of Management, 7(1), 45-62.

Larson, A. L., Teisberg, E. O., \& Johnson, R. R. (2000). Sustainable business: opportunity and value creation. Interfaces, 30(3), 1-12.

Linton, J. D., Klassen, R., \& Jayaraman, V. (2007). Sustainable supply chains: An introduction. Journal of Operations Management, 25(6), 1075-1082. doi 10.1016/j.jom.2007.01.012

Lucas, M. T. (2010). Understanding environmental management practices: integrating views from strategic management and ecological economics. Business Strategy and the Environment, 19(8), 543-556.

Nehrt, C. (1996). Timing and intensity effects of environmental investments. Strategic Management Journal, 17(7), 535-547.

Ninlawan, C., Seksan, P., Tossapol, K., \& Pilada, W. (2010). The implementation of green supply chain management practices in electronics industry. Proceedings of the International Multiconference of Engineers and Computer Scientists, Hong Kong, China, 1563-1568. 
Pazirandeh, A., \& Jafari, H. (2013). Making sense of green logistics. International Journal of Productivity and Performance Management, 62 (8), 889-904.

Porter, M. E. (1985). Competitive advantage: creating and sustaining superior performance. New York: The Free Press.

Porter, M. E., \& Heppelmann, J. E. (2014). How smart, connected products are transforming competition. Boston: Harvard Business Review.

Rao, P., \& Holt, D. (2005). Do green supply chain lead to competitiveness and economic performance? International Journal of Operations \& Production Management, 25(9), 898-916.

Ritzman, L. P., \& Krajewski, L. J. (2002). Foundations of operations management. Harlow: Prentice Hall.

Rothenberg, S., Pil, F. K., \& Maxwell, J. (2001). Lean green and the quest for superior environmental performance. Production and Operations Management, 10(3), 228-243.

Saridogan, M. (2012). The impact of green supply chain management on transportation cost reduction in Turkey. International Review of Management and Marketing, 2(2), 112-121.

Shrivastava, P. (1995). Environmental technologies and competitive advantage. Strategic Management Journal, 16(S1), 183-200. doi 10.1002/smj. 4250160923

Smith, D., \& Langfield-Smith, K. (2004). Structural equation modeling in management accounting research: critical analysis and opportunities. Journal of Accounting Literature, 23, 49-86.

Srivastava, S. (2007). Green supply chain management: a state of the art literature review. International Journal of Management Review, 9(1), 53-80.

United Nations Environment Programme. (2016). UN Environment Programme. Retrieved from http://www.unep.org/

Vachon, S., \& Klassen, R. D. (2006). Green project partnership in the supply chain: the case of the package printing industry. Journal of Cleaner Production, 14(6-7), 661-671.

Wetzels, M., Odekerken-Schroder, G., \& Oppen, C. van. (2009). Using PLS Path Modeling for assessing hierarchical construct models: Guidelines and empirical illustration. MIS Quarterly, 33(1), 177-195.

Woodward, J. (1970). Industrial organization: Behaviour and control. United Kingdom: Oxford University Press.

Zhu Q., \& Sarkis, J. (2004). Relationships between operational practices and performance among early adopters of green supply chain management practices in Chinese manufacturing enterprises. Journal of Operations Management, 22(3), 265-289. 


\title{
Zhu, Q., Geng, Y., Fujita, T., \& Hashimoto, S. (2010). Green supply chain management in leading manufacturers: Case studies in Japanese large companies. Management Research News, 33(4), 380-392.
}

\section{ABOUT THE AUTHORS}

\author{
ROBERTO GIRO MOORI \\ $\mathrm{PhD}$ in Production Engineering, \\ Universidade de São Paulo. \\ Full Professor in Business Administration, \\ Universidade Presbiteriana Mackenzie. \\ Rua da Consolação, 896, Centro - São Paulo - SP - Brazil - CEP 01302-907 \\ E-mail: roberto.moori@mackenzie.br \\ ORCID: 0000-0001-5690-746X
}

\section{FABIO YTOSHI SHIBAO}

$\mathrm{PhD}$ in Business Administration,

Universidade Presbiteriana Mackenzie.

Full Professor in Business Administration,

Universidade Nove de Julho.

Rua Deputado Salvador Julianelli, s/n - Prédio D - Barra Funda - São Paulo - SP - Brazil

CEP 01156-000

E-mail: fabio.shibao@gmail.com

ORCID: 0000-0002-6666-0330

\section{MARIO ROBERTO DOS SANTOS}

$\mathrm{PhD}$ in Administration,

Universidade Nove de Julho.

Rua Joaquim Casemiro, 397, Planalto - São Bernardo do Campo - SP - Brazil - CEP 09890-050

E-mail: mario.rsantos@terra.com.br

ORCID: 0000-0001-6222-9255

\section{EDITORIAL BOARD}

Editor-in-chief

Silvio Popadiuk

Associated Editor

Dimária Silva e Meirelles

Technical Support

Patricia Betencourt

Vitória Batista Santos Silva

\section{EDITORIAL PRODUCTION}

Publishing Coordination

Irina Migliari

Language Editor

Caio Rubens Salles

Editorial Trainee

Layout Designer

Maria Luiza Vanz

Emap

Copyeditor

Irina Migliari

Graphic Designer

Libro 


\section{ERRATA}

In the paper "Role of technology in the environmental performance of the Brazilian chemical industry", published in Revista de Administração Mackenzie-RAM (Mackenzie Management Review), 19(1), eRAMR180094:

- At page 27, it should be read in Mario Roberto dos Santos: "ORCID: 0000-0001-6222-9255”, instead of “ORCID: 0000-0002-5817-8907”. 